\title{
Transient TNF regulates the self-renewing capacity of stem-like label-retaining cells in sphere and skin equivalent models of melanoma
}

\author{
Pauline Ostyn ${ }^{1 \dagger}$, Raja El Machhour ${ }^{1 \dagger}$, Severine Begard ${ }^{1}$, Nuria Kotecki ${ }^{1}$, Jerome Vandomme ${ }^{1,2}$, Pilar Flamenco ${ }^{1}$, \\ Pascaline Segard ${ }^{1,2}$, Bernadette Masselot ${ }^{1,2}$, Pierre Formstecher ${ }^{1,2,3}$, Yasmine Touil ${ }^{1,4+}$ and Renata Polakowska ${ }^{1{ }^{*+}}$
}

\begin{abstract}
Background: It is well established that inflammation promotes cancer, including melanoma, although the exact mechanisms involved are less known. In this study, we tested the hypothesis that inflammatory factors affect the cancer stem cell (CSC) compartment responsible for tumor development and relapse.

Results: Using an inducible histone 2B-GFP fusion protein as a tracer of cell divisional history, we determined that tumor necrosis factor (TNF), which is a classical pro-inflammatory cytokine, enlarged the CSC pool of GFP-positive label-retaining cells (LRCs) in tumor-like melanospheres. Although these cells acquired melanoma stem cell markers, including ABCB5 and CD271, and self-renewal ability, they lost their capacity to differentiate, as evidenced by the diminished MelanA expression in melanosphere cells and the loss of pigmentation in a skin equivalent model of human melanoma. The undifferentiated cell phenotype could be reversed by LY294002, which is an inhibitor of the PI3KJAKT signaling pathway, and this reversal was accompanied by a significant reduction in CSC phenotypic markers and functional properties. Importantly, the changes induced by a transient exposure to TNF were long-lasting and observed for many generations after TNF withdrawal.

Conclusions: We conclude that pro-inflammatory TNF targets the quiescent/slow-cycling melanoma SC compartment and promotes PI3K/AKT-driven expansion of melanoma SCs most likely by preventing their asymmetrical self-renewal. This TNF effect is maintained and transferred to descendants of LRC CSCs and is manifested in the absence of TNF, suggesting that a transient exposure to inflammatory factors imprints long-lasting molecular and/or cellular changes with functional consequences long after inflammatory signal suppression. Clinically, these results may translate into an inflammation-triggered accumulation of quiescent/slow-cycling CSCs and a post-inflammatory onset of an aggressive tumor.
\end{abstract}

Keywords: Cancer stem cells, Quiescence, Label-retaining cell, Melanoma, TNF

\section{Background}

Human malignant melanoma is an extremely aggressive and drug-resistant skin cancer with poor prognosis if detected at an invasive stage. Despite advances in melanoma research and drug development, $10-20 \%$ of clinically disease-free patients relapse $5-10$ years following an initial treatment $[1,2]$. This phenomenon, which is known as tumor dormancy [3], has been related to the existence of

\footnotetext{
* Correspondence: renata.polakowska@inserm.fr

${ }^{\dagger}$ Equal contributors

'Inserm U837 Jean-Pierre Aubert Research Center, Institut pour la Recherche sur le Cancer de Lille (IRCL), 1, Place de Verdun 59045, Lille Cedex, France Full list of author information is available at the end of the article
}

therapy-resistant cells with stem-like activity [4-6]. Recent findings suggest that cancer stem cells, in response to chemotherapy, enter protective, prolonged, but reversible, quiescence [7] and remain dormant without causing any clinical manifestations until activated [8]. Once activated, cancer stem cells (CSCs) are responsible for melanoma reinitiation, tumor progression and increased tumor aggressiveness. Mechanisms that control quiescent tumor cell activation remain poorly understood; however, cellular interactions, the immediate microenvironment of various diffusible factors or immune surveillance may be responsible. The relatively well documented connection between

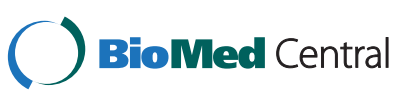

(c) 2014 Ostyn et al.; licensee BioMed Central Ltd. This is an Open Access article distributed under the terms of the Creative Commons Attribution License (http://creativecommons.org/licenses/by/4.0), which permits unrestricted use, distribution, and reproduction in any medium, provided the original work is properly credited. The Creative Commons Public Domain Dedication waiver (http://creativecommons.org/publicdomain/zero/1.0/) applies to the data made available in this article, unless otherwise stated. 
the incidence of cancer and chronic inflammation $[9,10]$ prompt us to study whether pro-inflammatory Tumor Necrosis Factor (TNF) is involved in the phenotypic switch of quiescent tumor cells into their active proliferative state in melanoma. This cytokine, which was discovered by Carswell et al. [11], is considered one of the major mediators of inflammation responsible for the development of many cancers $[12,13]$, including melanoma, upon exposure to ultraviolet radiation [14]. Using an inducible H2B-GFP tracing system, we demonstrated for the first time that TNF increases the sub-population of quiescent or slowcycling melanoma stem-like cells. This increase was associated with the increased self-renewal and sphere-forming abilities of melanoma cells in vitro and their tumor-like founding capacity in an in vivo-like model of human skin equivalents (SEs). More importantly, by a serial transplantation of SE-tumor cells using sphere-forming assays, we found that the tumor-founding cells maintain these TNFinduced properties for generations after first exposure and that this activity may be mediated by the PI3K/AKT signaling pathway.

\section{Results}

\section{Detection of label-retaining melanoma cancer stem cells} in vitro

Cancer stem cells (CSCs), similar to normal adult stem cells (SCs), remain quiescent most of the time and only infrequently enter the cell cycle to self-renew and to produce progeny committed to differentiation, composing most the tumor mass. This situation renders CSCs unable to dilute labels tracing a cell divisional history as fast as their transient amplifying (TA) progeny. Thus, these cells are recognized as the label-retaining cells (LRCs) in the tumor mass [15]. Using the in vivo study of Tumbar et al. [16] as a prototype, we constructed a tetracycline-inducible plasmid system expressing fused Histone B2 with Green Fluorescent Protein (H2B-GFP) and generated stably transfected clonal HBL and SK-Mel28 human melanoma cell lines (HBL-H2B-GFP and SK-Mel28-H2B-GFP, respectively). Without tetracycline, these cells were GFP-negative (Figure 1A, B), demonstrating that this system is not leaky. After $24 \mathrm{~h}$ of incubation with tetracycline (pulse period), $96.8 \% \pm 0.98$ of monolayer cells was labeled with GFP. A parallel flow cytometry (Figure 1A) and live cell imaging analysis (Figure 1B, C) determined that cells lost the GFP-emitted fluorescence as the cells proliferated in the tetracycline-free medium (chase period). Importantly, cell cycle progression was not affected by the H2B-GFP fusion protein ([17] and our observation). At day 9, 2.8\% \pm 1.8 of cells still retained their labels (Figure 1B, C); however, all cells eventually lost their labels (not shown), indicating that the monolayer culture conditions are incompatible with long-term cellular quiescence and that all cells divide, although some are slower than others.
To recapitulate the more tumor-like conditions, we traced the GFP dilution in 3D sphere cultures formed by the tetracycline-induced HBL-H2B-GFP and SK-Mel 28-H2B-GFP cells. After 7 days of chase in tetracyclinefree sphere-forming medium, only individual cells within melanospheres retained a high level of GFP $\left(\mathrm{GFP}^{\text {high }}\right)$ (Figure 2A, left). Other cells fluoresced with a different intensity (Figure 2A, right), revealing heterogeneity in the proliferation rate within melanosphere cells. A double parameter flow cytometry assay evaluating a proportion of EdU-positive $\left(\mathrm{EdU}^{+}\right) \mathrm{S}$-phase cells in the GFP $^{\text {high }}$ and GFP-negative (GFP ${ }^{\text {low }}$ ) subsets of melanosphere cells established that the GFP ${ }^{\text {high }}$ subset contained significantly $(\mathrm{p}<0.05)$ less EdU ${ }^{+}$cells after $2 \mathrm{~h}$ of labeling than their GFP $^{\text {low }}$ HBL-H2B-GFP counterparts (Figure 2B). Together with the above observations, an analogous decrease (1.8-fold) in the $\mathrm{EdU}^{+} \mathrm{GFP}^{\text {high }}$ subset of SKMel28-H2B-GFP demonstrates the relative replicative quiescence of GFP ${ }^{\text {high }}$ cells. Reversibly quiescent or slowcycling cells were shown to have a SC phenotype $[15,16,18]$. A comparative flow cytometry analysis of stem cell markers with the GFP content revealed that the GFP ${ }^{\text {high }}$ melanosphere cell subset was enriched in cells expressing well established melanoma stem cell markers, including ABCB5 [19], CD271 (p75 $\left.{ }^{\mathrm{NTR}}\right)$, [20] and VEGFR1 [21]; a marker of neural crest stem cells, HNK1 (CD57) [22]; and Notch1, which is a common marker for many stem cell types [23] (Figure 2C). Figure 2D shows representative flow cytometry analysis for the ABCB5 marker. In summary, these data demonstrate that the pool of GFP ${ }^{\text {high }}$ melanosphere cells is enriched in quiescent/slow-cycling melanoma SCs that can be easily distinguished from their fast-cycling TA GFP $^{\text {low }}$ progeny.

\section{Pro-inflammatory TNF increases the proportion of label-retaining melanoma stem cells}

Equipped with a tool that distinguishes stem from nonstem cells and knowing that chronic inflammation predisposes tissues to cancer $[9,13]$, we aimed to determine whether inflammation affects the SC pool in melanoma, thus providing a missing link between inflammation and tumor development. The most prominent and bestcharacterized pro-inflammatory cytokine present in the site of inflammation is TNF [24,25], and reversible quiescence is one of the hallmarks of SCs. TNF dramatically decreased the proportion of melanosphere cells resting in the quiescent G0 phase of the cell cycle, reaching the level of adherent monolayer cultures (Figure 3A). This finding suggested that TNF stimulates the cycling of quiescent melanoma SCs. Because CSCs are defined by their LRC properties, we determined the effect of TNF on the quiescent/slowcycling $\mathrm{GFP}^{\text {high }}$ subpopulation in the untreated and TNF-treated melanospheres formed by fluorescing HBLH2B-GFP and SK-Mel28-H2B-GFP cells. The proportion 

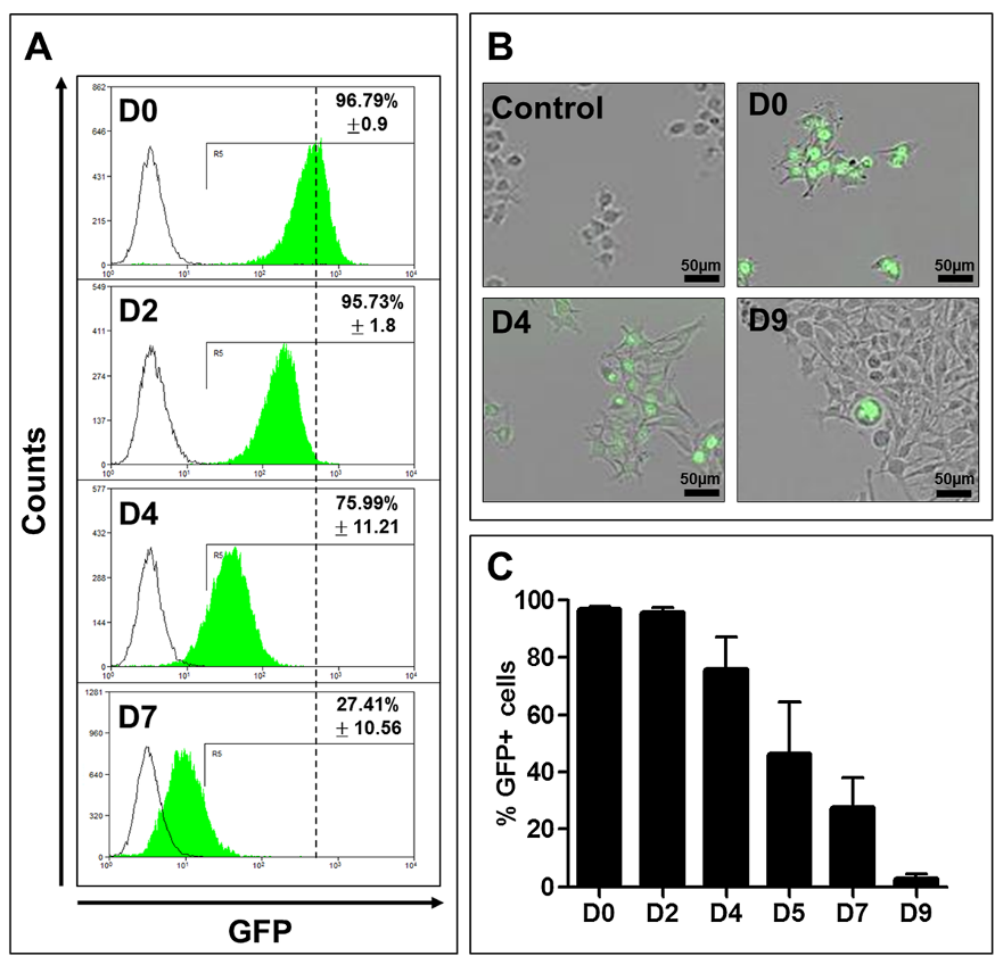

Figure 1 Dividing cells with diluted Histone 2B-Green Fluorescent Protein (H2B-GFP) fusion protein monitoring cell divisional history. HBL and SK-Mel28 melanoma cells were stably transfected with the "TET-ON" plasmid system (Materials and methods) to express inducible H2B-GFP. A. Flow cytometry analysis of GFP fluorescence at day (D) 0, 2, 4 and 7. GFP-negative tetracycline-uninduced cells (black lines) served as reference to gate their GFP-positive (green lines) counterparts. The numbers indicate the percent of GFP-positive cells in the total population. B. Representative IncuCyte images of live cell video recordings made during 9 days of culturing and illustrating a progressive dilution of GFP. Control - uninduced HBL-H2BGFP cells. Scale bar $=50 \mu \mathrm{m}$. C. Quantitative illustration of GFP dilution during 9 days of culturing.

of gated live GFP ${ }^{\text {high }}$ cells in the control HBL-H2B-GFP and SK-Mel28-H2B-GFP melanospheres amounted to $4.3 \% \pm 1.4$ and $6.2 \% \pm 0.2$, respectively, and TNF augmented their proportion to $9.2 \% \pm 2.4$ and $9.6 \% \pm 1.5$, respectively (Figure $3 \mathrm{~B}$ ). This result suggests that TNF expands the pool of LRC-GFP ${ }^{\text {high }}$ cells in melanospheres either by a few (not exhausting GFP fluorescence) rounds of symmetric division or by suppressing cycling of dividing melanoma SCs. When compared with the starting intensity, a general decrease in the GFP fluorescence intensity indicates that GFP ${ }^{\text {high }}$ cells divide, thus favoring the former possibility but not excluding the latter. Similar to normal SCs, CSCs can be recognized by their ability to proliferate as non-adherent tumor-like spheres, and a sphere-forming unit (SFU) value is an approximate indicator of the size of the SC pool [26-28]. We assessed the effect of TNF on the sphere-forming ability of HBL-H2B-GFP and SK-Mel28H2B-GFP cells with the wild type and mutated $B R A F^{V 600 E}$, respectively. Mutated $\mathrm{BRAF}^{\mathrm{V} 600 \mathrm{E}}$ is constitutively active in approximately $50 \%$ of human melanomas, causing their uncontrolled proliferation [29]. TNF significantly stimulated tumor-like sphere formation in both cell lines (Figure 3C), indicating that the TNF effect is $\mathrm{BRAF}^{\mathrm{V} 600 \mathrm{E}}$-independent and confirming that TNF expands the melanoma SC pool.
As expected for melanoma SCs, live $\mathrm{GFP}^{\text {high }}$ cells overexpressed ABCB5 and CD271 surface markers, conferring their CSC phenotype $[19,20,30]$, and consistently, TNF significantly $(\mathrm{p}<0.01)$ increased the pool of $\mathrm{GFP}^{\text {high- }}$ $\mathrm{ABCB} 5^{\text {high }}$ (Figure 3D) and $\mathrm{GFP}^{\text {high }} \mathrm{CD} 271^{\text {high }}(2.0 \mathrm{x} \pm 0.2$, data not shown) cells in HBL-H2B-GFP and, to a lesser extent, in SK-Mel28-H2B-GFP $(1.6 \mathrm{x} \pm 0.2$ and $1.7 \mathrm{x} \pm 0.6$, respectively, data not shown) cell lines. Altogether, these data infer that TNF expands the pool of GFP high $\mathrm{ABCB}^{\text {high }} \mathrm{CD} 271^{\text {high }}$ sphere-initiating melanoma SCs. Because spheres are more tumorigenic than their adherent counterparts when grafted into severe combined immunodeficiency disease (SCID) mice [31] and because the CSC compartment is responsible for tumor development and for the severity of breast cancer [15], we presumed that TNF also predisposes to melanoma and a higher tumor burden by increasing in the CSC compartment.

TNF inhibits melanoma cell differentiation and induces transferable changes affecting the size of the melanoma SC pool in 3D tumor-like sphere and organotypic skin models To determine functional consequences of the TNF-instigated changes leading to the increase in $\mathrm{GFP}^{\text {high }}$ cells with the melanoma SC phenotype, we performed functional 

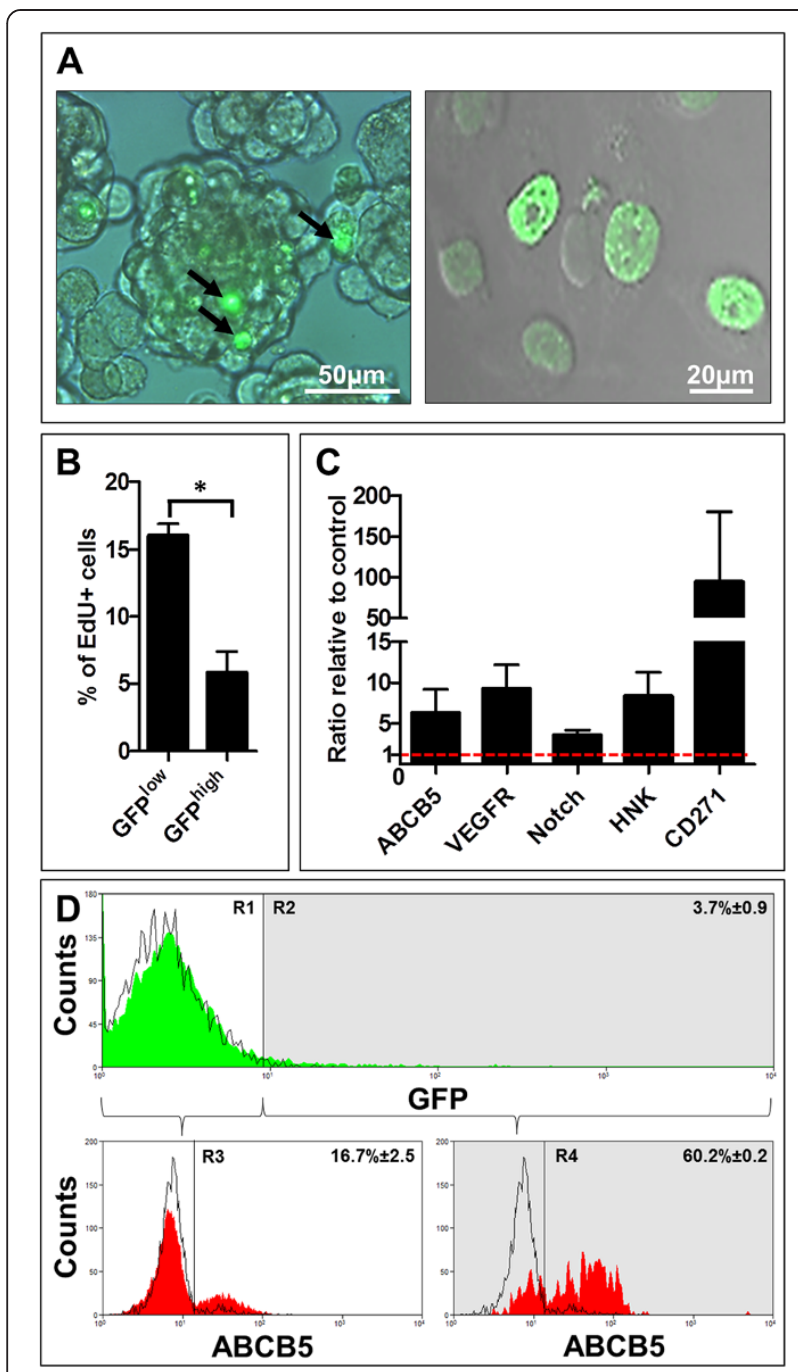

Figure 2 Melanospheres contain a small subpopulation of quiescent/slow-cycling GFPhigh label-retaining cells (LRCs) with a melanoma stem cell phenotype. A. Representative melanospheres (left panel, scale bar $=50 \mu \mathrm{m}$ ) formed by HBL-H2BGFP cells dividing at different rates, as reflected by differences in the GFP fluorescence intensity between dissociated melanosphere cells (right panel, scale bar $=20 \mu \mathrm{m})$. B. GFPhigh melanosphere HBL cells cycle slower and incorporate less EdU than their GFPlow counterparts. C. These GFPhigh cells overexpress stem cell surface markers. Histogram illustrating the ratio of expression of each marker in GFPhigh cells to their own GFPlow controls, which were set at "1" and marked by the red interrupted line. D. Representative histograms of flow cytometry data for the surface ABCB5 marker in melanosphere HBL-H2BGFP cells. Upper histogram illustrates GFP (green) fluorescence distribution in total population. R1 is a region encompassing GFP negative (black lines) and GFPlow subset and R2 GFPhigh subpopulation (shaded). Lower histograms show ABCB5 distribution between GFPlow and GFPhigh (shaded) subpopulations. R3 is a boundary drawn around $\mathrm{ABCB} 5^{\text {high }}$ cells within GFPlow subset and R4 within GFPhigh subpopulation. Numbers indicate percentage of cells with a particular phenotype.

tests (Figure 4A) using tumor-like sphere cultures. Tetracycline-induced (pulse) monolayer HBL-H2B-GFP and SK-Mel28-H2B-GFP cells were used to generate spheres in the presence or absence of TNF in tetracycline-free (chase) medium for 7 days. Dissociated and sorted quiescent $\left(\mathrm{GFP}^{\text {high }}\right)$ and TA actively cycling $\left(\mathrm{GFP}^{\mathrm{low}}\right)$ untreated and TNF-treated melanosphere cells were assayed for their ability to form secondary spheres and colonies in the absence of TNF. This experiment was designed to allow the identification of a TNF responding subpopulation and the estimation of the proportion of sphere-initiating CSCs in the first generation of melanospheres. The same number of sorted GFP ${ }^{\text {high }}$ TNFexposed melanosphere cells produced more secondary spheres (Figure 4B) and colonies (Figure 4C) than their unexposed counterparts despite TNF absence. In contrast, exposed GFP ${ }^{\text {low }}$ cells formed fewer spheres and colonies then their unexposed controls. This result demonstrates 2 important events: one, that the transient exposure to TNF induces changes that persist for generations after TNF withdrawal, and two, that this long-term TNF effect is exclusively maintained by GFP ${ }^{\text {high }}$ CSCs. This finding suggests that TNF imprints transferable molecular changes that permanently affect the functionality of the melanoma GFP ${ }^{\text {high }} \mathrm{SC}$ compartment.

To gain insight into the possible cellular mechanism(s) by which TNF maintained its effect, we recapitulated melanoma in an in vivo-like $[32,33]$ skin equivalent (SE) model, which is an alternative to animal models, using sorted quiescent $\left(\mathrm{GFP}^{\text {high }}\right)$ and fast-cycling $\left(\mathrm{GFP}^{\text {low }}\right)$ cells in the presence or absence of systemic TNF for 3 weeks. Interestingly, control GFP ${ }^{\text {high }}$ HBL-H2B-GFP cells (Figure 4D) and, to a lesser extent, SK-Mel28-H2B-GFP (not shown) cells were capable of developing into the highly pigmented assembly of cells resembling melanoma tumor in vivo. TNF apparently limited this process in GFP ${ }^{\text {high }}$ SEs and had no effect on GFP ${ }^{\text {low }}$ SEs, which contained only a few pigmented spots. These data underline the superior tumor regeneration potential of the $\mathrm{GFP}^{\text {high }}$ cells over their $\mathrm{GFP}^{\text {low }}$ counterparts and suggests that chronic TNF either specifically eradicates the majority of GFP ${ }^{\text {high }}$ cells in SEs or suppresses their differentiation. The presence of some pigmented spots in all SEs independent of the condition indicates a differential cellular response to environmental clues and suggests that both $\mathrm{GFP}^{\text {high }}$ and $\mathrm{GFP}^{\text {low }}$ cell compartments are heterogeneous and that the GFP ${ }^{\text {low }}$ compartment contains a small subpopulation of cells with SC activity but are phenotypically undistinguishable from the non-stem GFP $^{\text {low }}$ cells, ratifying our earlier findings [34].

To resolve whether TNF eradicates or blocks GFP ${ }^{\text {high }}$ cell differentiation, SE cells were recovered and assayed for their sphere-forming abilities. Apparently, GFP ${ }^{\text {high }}$ cells were not eradicated because these cells initiated the formation of more spheres (Figure 4E) when derived from TNF-treated SEs. Consistent with a study by Landsberg et al. [35], this result indicates that TNF 

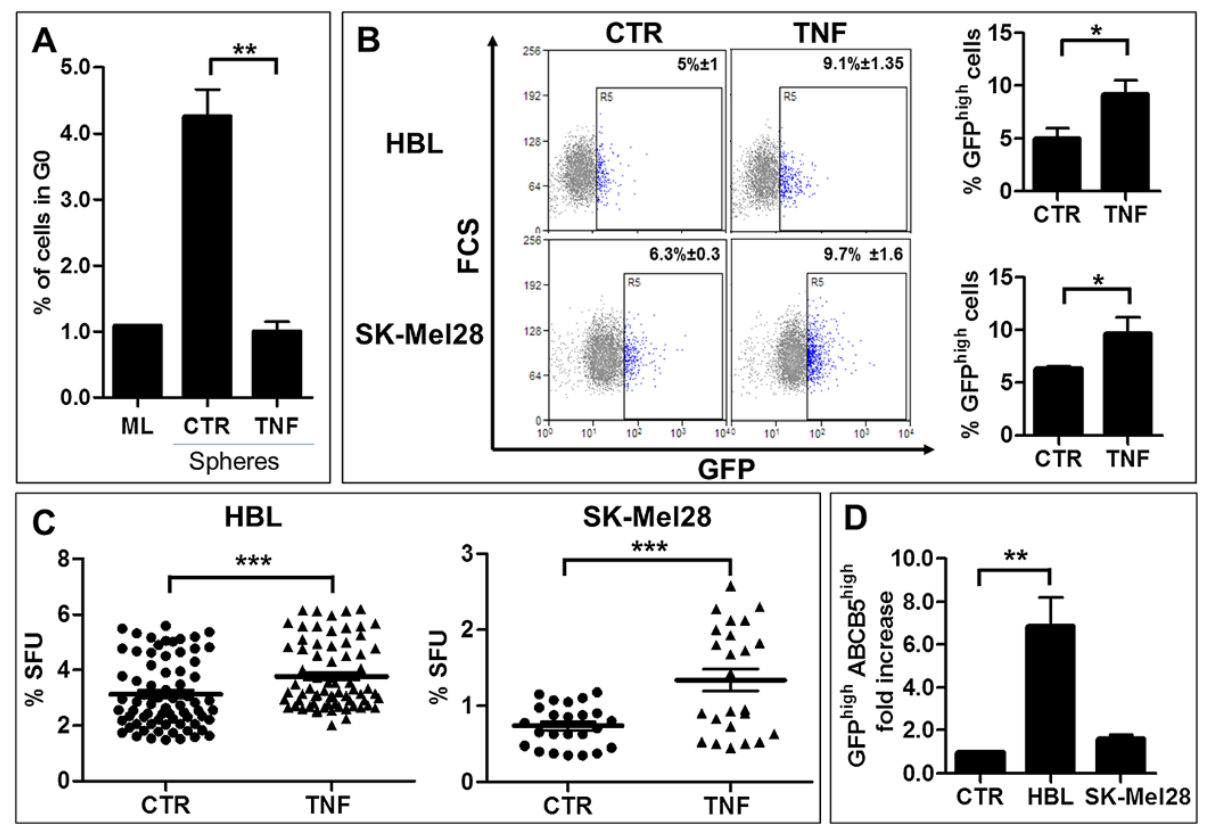

Figure 3 TNF enlarges the stem-like cell compartment in human melanomas in vitro. A. TNF decreased the proportion of melanosphere cells resting in the $\mathrm{GO}$ phase of the cell cycle to the level found in adherent monolayer (ML) cultures. TNF $(0.5 \mu \mathrm{g} / \mathrm{ml})$ was added at the time of seeding cells for a sphere-forming assay. After 7 days, melanosphere cells were dissociated, reacted with an anti-Ki67 primary antibody and an anti-mouse Cy5 secondary antibody, and then stained with propidium iodide (PI) before performing the flow cytometry analysis. Ki67-negative cells in the G0/G1 fraction were considered the G0 quiescent cells. B. Flow cytometry of dissociated melanosphere cells revealed that TNF increased the proportion of GFPhigh cells. Representative dot plot data and the corresponding \% of GFP-positive cells (left panel) and summary histograms of all data (right panel). C. TNF stimulates stem cell-related sphere-forming abilities in HBL and SK-Mel28 melanoma cell lines. D. TNF increases expression of ABCB5, which is a melanoma stem cell surface marker, in GFPhigh cells (GFP ${ }^{\text {high }} A B C B 5^{\text {high }}$ ) when compared to GFPhigh cells in untreated controls (CTR) set at "1" for each cell line. ${ }^{* * *} p<0.001 ;{ }^{* *} p<0.01 ;{ }^{*} p<0.05$.

inhibited the melanoma GFP ${ }^{\text {high }}$ cell differentiation fate. However, in Landsberg et al. study, this effect was massively reversible at the molecular level. We concluded that the TNF-induced changes targeting melanoma SC compartment are irreversible, at least at the functional level, because the TNF-reduced pigmentation was linked to a steadily increasing number of secondary and tertiary spheres formed by the sorted GFP ${ }^{\text {high }}$ cells dissociated from the first generation TNF-treated melanosphere in the absence of TNF (Figure 4E). A small effect of TNF on GFP $^{\text {low }}$ and unexposed melanosphere cells confirms the existence of actively dividing CSCs $[34,36]$ within the nonSC GFP ${ }^{\text {low }}$ cell subset. However, their number tended to decrease with further generations, suggesting that the GFP $^{\text {low }}$ cells in the TNF-free environment progressively exhaust their sphere-initiation and repopulation capacity, which is apparently well preserved by the GFP ${ }^{\text {high }}$ cell subset that seems to attain a TNF-exposure "memory". Interestingly, these capacities appear to be specifically restricted by the SE environment since unexposed GFP ${ }^{\text {low }}$ SE cells generated fewer spheres then unexposed GFP ${ }^{\text {low }}$ sphere cells (Figure 4B vs 4E). Collectively, all the above data demonstrated that melanoma cell lines contain a small pool of $\mathrm{GFP}^{\text {high }} \mathrm{ABCB} 5^{\text {high }} \mathrm{CD} 271^{\text {high }}$, quiescent/slow-cycling, self-renewing, melanoma stem-like cells that lose their ability to differentiate when targeted by TNF, even transiently, and that these cells appear to transfer this effect to further generations and manifest post-TNF exposure.

Inactivation of the PI3K/AKT signaling pathway abolishes the TNF effect on the melanoma stem cell compartment

TNF-suppressed differentiation, which was accompanied by an increase in $\mathrm{GFP}^{\text {high }} \mathrm{ABCB} 5^{\text {high }}$ sphere-initiating melanoma SCs, strongly suggests that TNF blocks the commitment of these cells to differentiation, favoring their symmetric over asymmetric self-renewal. One of the important regulators of SCs, including CSC fate, is the AKT signaling pathway [37-39]. Among its multiple functions, AKT has been shown to block the differentiation of myeloid leukemia [40] and embryonic stem cells [41]. A deregulated AKT signaling pathway is often found in melanoma [42,43], and we previously demonstrated that this pathway regulates melanoma SC quiescence [34]. Consistent with the previous findings, TNF also phosphorylated AKT in melanosphere cells (Figure 5A), and this phosphorylation was associated with the suppression of the differentiation-related MelanA 

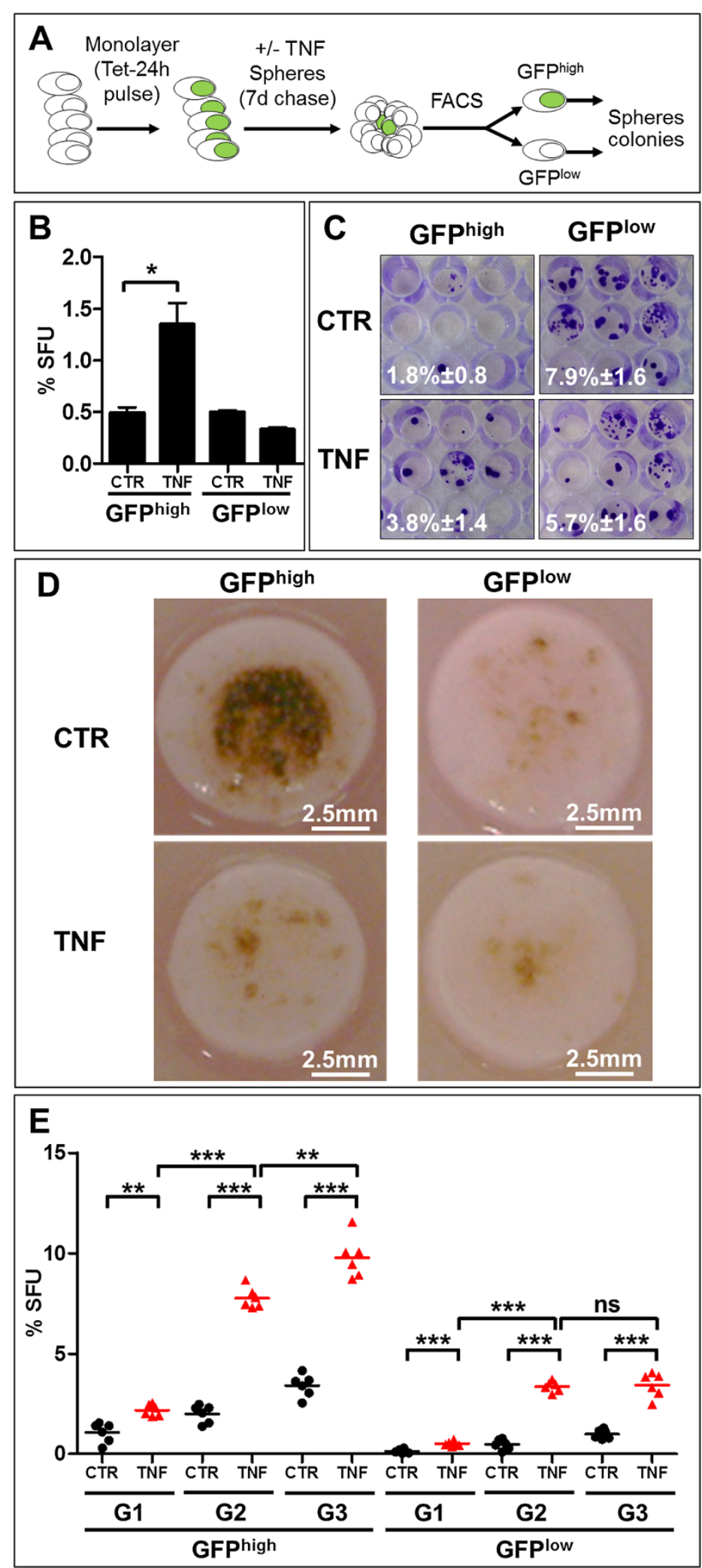

Figure 4 (See legend on next page.) 
(See figure on previous page.)

Figure 4 Transient exposure to TNF induces irreversible functional changes in the GFPhigh stem-like cell compartment. A. Schematic representation of the experimental design. Green nuclei refer to GFP-positive cells. B. TNF affects the pool of self-renewing GFPhigh cells. Tetracycline-induced HBL-H2BGFP melanoma cells formed melanospheres in the presence or absence of TNF that 7 days later were dissociated, and cells were sorted by FACS. The GFPhigh and GFPlow cells were assayed for their sphere- (B) and colony (C)-forming abilities in TNF-free medium. The histograms represent accumulated data from 24 individual samples. C. Representative image of clonogenic assay. The numbers indicate the $\%$ of colony-forming units. D. TNF blocks melanoma cell maturation. Representative skin equivalents (SEs) co-cultured with HBL melanoma cells and untreated or treated with TNF $(0.5 \mu \mathrm{g} / \mathrm{ml})$ for 3 weeks with TNF added to fresh medium, which was changed every 3 days. Experiments were repeated 3 times. E. Control (CTR-black) or TNF-treated (TNF-red) dissociated SE cells were evaluated for their ability to generate successive generations of spheres in TNF-free medium. The first (G1), second (G2) and the third (G3) generation spheres were formed during 7 days. ${ }^{* *} p<0.001 ;{ }^{* *} p<0.01$.

expression overridden by LY294002, which is an inhibitor of the PI3K/AKT signaling pathway (Figure 5B). These data suggested that AKT might mediate the TNF-initiated inhibition of melanoma differentiation. A significant $(\mathrm{p}<0.001)$ reduction in the sphere-forming capacity of melanosphere cells generated in the presence of LY204002 (Figure 5C) demonstrated that the sustained inactivation of AKT signaling reduced the melanoma SC compartment most likely by switching from symmetric to asymmetric self-renewal and by releasing the TNF-suppressed differentiation fate of melanoma SCs. Consistently, LY294002 suppressed the TNF-induced upregulation of $\mathrm{GFP}^{\text {high }} \mathrm{ABCB} 5^{\text {high }}$ melanoma $\mathrm{SCs}$ (Figure 5D), strongly supporting AKT involvement in the TNF-mediated regulation of melanoma SC fate determination and functionality. Finally, because TNFactivated AKT targets $\mathrm{NFKB}$, which is a well-known mediator of TNF responses [44-46] that control SC fate [47], and because NFKB can target AKT $[48,49]$, evidencing a cross-talk between these pathways [49,50], we used the NFKB inhibitor BAY 11-7082 in combination with TNF to form melanospheres. This inhibition should distinguish which of the two pathways mediates TNF responses. As shown in Figure 5D, the NFkB inhibitor did

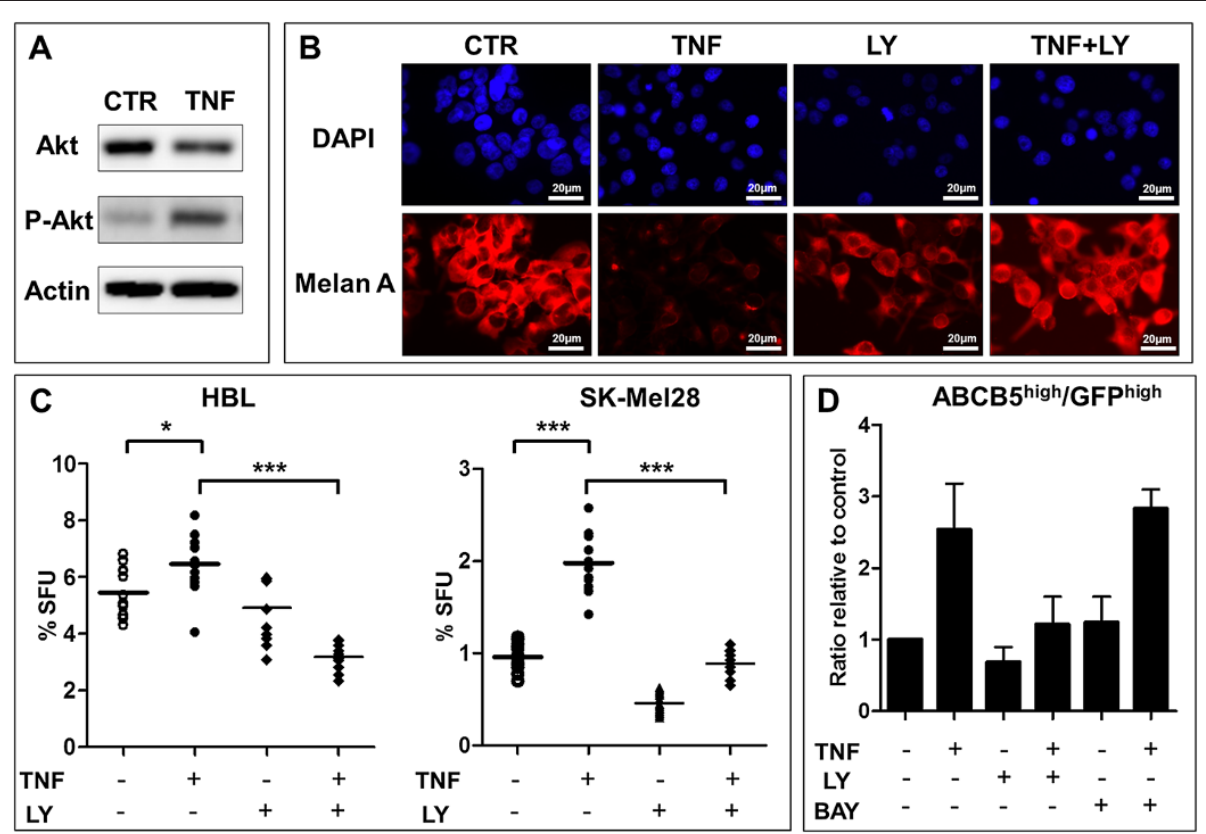

Figure $5 \mathrm{TNF}$ expands the subset of GFP $\mathrm{P}^{\text {high }} / \mathrm{ABCB} 5^{\text {high }}$ melanoma stem-like cells through the AKT-signaling pathway. A. Representative image of western blot $(n=2)$ analysis showing an increase in phosphorylated (p)-AKT in spheres formed by HBL melanoma cells cultured in the presence of TNF $(0.5 \mu \mathrm{g} / \mathrm{ml})$. Actin served as a loading control. B. Representative fluorescent microscopy images showing that LY294002 (10 $\mu \mathrm{M})$ addition at sphere seeding in the presence or absence of TNF stimulates Melan A expression, and the morphological differentiation of melanospheres was inhibited by TNF. For each condition spheres were collected from 24 wells before dissociation and immunocytochemistry analysis. Scale bar $=20 \mu \mathrm{m}$. C. PI3K/AKT inactivation blocked the TNF-induced melanoma SC-related ability to form spheres. Melanospheres were formed in the presence or absence of TNF $(0.5 \mu \mathrm{g} / \mathrm{ml})$ and LY294002 $(10 \mu \mathrm{M}) .{ }^{*} \mathrm{p}<0.05 ;{ }^{* * *} \mathrm{p}<0.001$. The data represent 2 independent experiments in 3 repetitions. D. Flow cytometry data showing that the PI3K AKT inhibitor LY294002 (10 $\mu \mathrm{M})$ added at seeding decreased the proportion of TNF-induced ABCB5 ${ }^{\text {high }}$ cells in melanospheres formed by TNF-treated HBL cells. Note that the NFKB inhibitor BAY 11-7082 (1 $\left.\mu \mathrm{M}\right)$ did not repress TNF-mediated induction. Data of at least 2 independents each combining spheres from 24 wells. 
not affect the TNF-induced upregulation of GFP $\mathrm{P}^{\text {high- }}$ $\mathrm{ABCB} 5^{\text {high }}$ melanoma SCs, demonstrating that this effect is linked to $\mathrm{AKT}$ rather than $\mathrm{NFKB}$ activation.

\section{Discussion}

Reversible cellular quiescence is a hallmark of SCs. This ability protects these cells from a harsh environment and prevents their exhaustion imposed by constant cycling $[18,51,52]$. CSC entry into cellular quiescence and their post-therapeutic persistence in an apparently dormant state may be one reason why curing cancer remains difficult. Dormant cells can be activated and re-initiate tumor growth locally and in distant metastatic sites $[1,53]$. The exact molecular factors and cellular mechanisms governing the quiescence and activation of dormant CSCs have been intensely investigated but remain unclear, highlighting the requirement for additional research in this area. Because inflammation has been functionally related to cancer evolution and because inflammatory signals have been shown to regulate the quiescence/activation of cancer and normal SCs $[8,10,47,54,55]$ but not much is known concerning the circuitries connecting inflammation to melanoma development, we examined the effect of TNF, which is one of the major mediators of cancerrelated inflammatory responses [9], on melanoma cell quiescence and melanoma development in 3D tumor-like sphere and in vivo-like reconstructed skin models. Using an inducible H2B-GFP system to trace the cell divisional history in vitro, we identified quiescent/slow-cycling GFP $^{\text {high }}$ label-retaining CSCs in melanoma cell lines and showed that transient and chronic TNF suppresses melanoma SC differentiation while enriching for a GFP ${ }^{\text {high }}$ melanosphere-initiating CSC subpopulation many generations after TNF withdrawal. This finding is consistent with a model in which inflammatory TNF signals imprint transferrable changes in the melanoma SC subpopulation, permanently affecting their fate and function and, consequentially, their progressive post-TNF expansion. Because the size of the CSC compartment is directly linked to a tumor burden [56], by enlarging this compartment, TNF may cause a predisposition to melanoma development and evolution. Our findings suggest that TNF may achieve this effect by activating the PI3K/AKT signaling pathway.

AKT signaling, which is often constitutively active in melanoma cells and in other cancer cells, regulates many cellular processes, including cell survival, metabolism and cell cycle progression $[37,57,58]$. Interestingly, recent findings indicate that $\mathrm{AKT}$ is a particularly important determinant of SC function because AKT controls SC quiescence, propagation and fate [37-40]. Recently, we demonstrated that quiescent melanoma SCs exit the G0 phase of the cell cycle in response to transient AKT inactivation; however, their cycling subset enters the quiescent state, whereas sustained AKT inhibition suppresses cell cycle progression [34]. In the present study, we found that LY294002, which is an inhibitor of PI3K/AKT, specifically blocked the TNF-driven enrichment of melanospheres in GFP $^{\text {high }}$ label-retaining cells with the CSC phenotype and activity. This inhibition was accompanied by the acquisition of dendritic cell morphology and by the overexpression of the melanocyte differentiation marker MelanA. These data demonstrate that PI3K/AKT inactivation stimulated melanoma GFP high cell differentiation, suggesting that TNF suppresses their commitment to the differentiation fate by activating $\mathrm{AKT}$, consequently preventing asymmetric self-renewal and promoting symmetric self-renewal of GFP ${ }^{\text {high }}$ melanoma SCs. This interpretation is consistent with the observed TNF-driven increase in the proportion of $\mathrm{GFP}^{\text {high }}$ cells and in the sphere-forming efficiency as well as with the inhibition of $\mathrm{GFP}^{\text {high }}$ CSC melanogenesis in SEs and with the simultaneous acquisition of sphere-forming abilities by the SE melanoma cells. Therefore, it appears that one mechanism by which TNF and, in general, inflammation may cause cancer predisposition is a blockage of the differentiation fate in CSCs, at least partially preventing the generation of their fast-cycling destined-to-differentiate progeny. Logically, this mechanism would maintain CSCs in their primitive, quiescent/slow-cycling state and lead to their slow, but continuous, accumulation particularly because the TNF-induced changes seem to be perpetuated in the offspring of CSCs after TNF withdrawal. Currently, the mechanism of this event is unknown. Very recently Wilson et al. [59] have reported that melanoma SC maintenance is dependent on ABCB5-dependent secretion of Il1 $\beta$ another inflammatory cytokine. Is TNF-induced $\mathrm{ABCB} 5$ part of this regulatory circuit? Importantly however, the precedence of the transient induction of heritable changes after removing a stimulus has already been linked to the epithelial-to-mesenchymal transition process, creating self-renewing breast cancer stem cells from a nonstem cell population [60,61]. In another study, a "memory" of transitory FGF had a long-lasting effect on the fibroblast response to the secondary FGF stimulation; this memory reduced rather than increased their proliferation [62]. These findings underscore epigenetics and chromatin structure in controlling long-term responses, including the generation of CSCs and their phenotypic plasticity [63]. Whether similar molecular and cellular changes can be ascribed to the TNF long-lasting action remains to be investigated. However, TNF was shown to induce EMT and to create a permissive environment for a "non-CSC to CSC" conversion in breast cancer [64], and our data do not exclude the possibility that this mechanism could be responsible for the TNF-induced changes in the melanoma SC compartment. Notably, recent data provided evidence for cell competition as yet another mechanism leading to the selection and expansion of the best-fitted 
cell (review see [65-67]), which could theoretically also be responsible for the selection of the best-fitted melanoma $\mathrm{SC}$ in the TNF environment and their post-TNF expansion. Nevertheless, although the above mechanisms are possible, in the absence of evidence, these mechanisms remain yet to be proven options.

The TNF-induced differentiation repressing mechanism, which is mediated by the PI3K/AKT signaling pathway, seems to be the most probable explanation of our results and is strongly supported by the findings of other researchers. For example, TNF was shown to induce the reversible dedifferentiation of melanoma cells [35] and an increased melanocyte number while inhibiting their differentiation-related pigmentation [68]. Similarly, TNF promotes neural stem (NSC) cell proliferation but inhibits their differentiation [69] and maintains osteosarcomas in their undifferentiated state [70]. Additionally, in the hematopoietic system, TNF was shown to have a stimulatory growth effect on hematopoietic stem cells (HSCs) but to negatively regulate the growth of their more mature progenitors in vitro [71]. In contrast, recent findings revealed that TNF suppresses cycling HSCs and their longterm repopulating activity in vivo [72] and in vitro [73], indicating that although the TNF pathway is a critical regulator of HSC maintenance and function (reviewed in [47]), the stimulatory and/or repressive effect of TNF will depend on cell types, the responding compartment and the cell status within each compartment. Little is known concerning the effect of TNF on the melanoma SC compartment. We [34] and others [74] have shown that this compartment is heterogeneous and, as we suggested, that this compartment is composed of CSCs in at least 3 different states: quiescent, slow-cycling and fast-cycling, which are each identified by distinct phenotypes and which each have a different mode of response to environmental changes. Roesch et al. [74] determined that the slowcycling melanoma cells, which were identified in our study as GFP ${ }^{\text {high }}$ cells, have the particular ability to switch between these phenotypes by assuming a distinct epigenetic state regulated by histone demethylase. Melanoma tumor growth depends on the presence of these cells. Consistently, the GFP ${ }^{\text {high }}$ cells in our reconstitution assay using an in vivo-like skin equivalent model were significantly more efficient in reproducing pigmented lesions resembling melanoma in vivo than their faster proliferating counterparts. This ability was suppressed by TNF, which simultaneously induced the number of melanosphereinducing $\mathrm{GFP}^{\text {high }}$ cells. In melanospheres, these cells coexisted with their GFP ${ }^{\text {low }}$ progeny and persisted, although many divisions were required to form a melanosphere. This finding indicates that TNF, while blocking the differentiation fate of slow-cycling cells, reverses at least some of these cells into a quiescent state to prevent their exhaustion. These data strongly suggest that TNF maintains melanoma SCs in their primitive state and controls their plasticity. One pathway that is responsible for this effect is PI3K/AKT signaling, which regulates "stemness" in many stem cell systems [38] and was shown to be selectively inactivated in one of the symmetrically dividing cells to induce quiescence in one daughter while another continues to divide [75].

\section{Conclusions}

In conclusion, we determined that transient TNF suppresses the PI3K/AKT-mediated melanoma SC differentiation and enlarges a GFP ${ }^{\text {high }}$ melanosphere-initiating CSC subpopulation that preserves the TNF-instigated changes, reinforcing their post-TNF capacity to form tumor-like melanospheres. These findings may have important clinical consequences because an acute inflammation may activate and expand pre-existing altered cells that remain clinically silent for generations until these cells emerge in a post-inflammatory environment as a primary or metastatic tumor in a more aggressive form.

\section{Materials and methods \\ Cell line and cell culture}

The human cutaneous melanoma cell line HBL was established in Professor Ghanem's laboratory from a nodular malignant melanoma [76]. These cells were maintained in RPMI (Gibco ${ }^{\oplus}$, Life Technologies ${ }^{\mathrm{Tm}}$, France) supplemented with $10 \%$ fetal bovine serum (FBS) (Lonza, Verviers, Belgium) and 1\% penicillin/streptomycin (Gibco ${ }^{\circ}$, Life Technologies ${ }^{\mathrm{Ts}}$, France) in a humidified $5 \% \mathrm{CO}_{2}$ incubator at $37^{\circ} \mathrm{C}$. The medium was changed every 3 days. The SK-Mel28 cells were purchased from ATCC (HTB-72) and grown as recommended. Primary keratinocyte and fibroblast cultures were established using specimens of adult skin discarded after breast plastic surgery (Hôpital Roger Salengro, CHRU, Lille, France) as described previously [77]. The storage and use of human biological samples were declared and performed according to the local Person's Protection Committee and to the ethical rules approved by the Department of Health, France. Keratinocytes were maintained in defined K-SFM $\left(\mathrm{Gibco}^{\circ}\right.$, Life Technologies $^{\mathrm{Tm}}$, France) supplemented with $1 \%$ penicillin/ streptomycin $\left(\mathrm{Gibco}^{\oplus}\right.$, Invitrogen ${ }^{\mathrm{TM}}$, France). Fibroblasts were cultured in RPMI supplemented with 10\% fetal bovine serum (FBS) and 1\% penicillin/streptomycin.

\section{Construction of plasmids and generation of stable transfectants expressing inducible H2B-GFP}

To accomplish the tetracycline-inducible expression of fused histone 2B-green fluorescent protein (H2B-GFP), we cloned the Taq polymerase-amplified H2B-GFP gene from Addgene into the PCR8/GW/TOPO entry vector and then into the pT-Rex DEST30 destination vector using the Invitrogen Gateway cloning system and Clonase 
II enzyme mix. The constructed pT-Rex DEST30-H2BGFP plasmid was used for the Lipofectamine-mediated transfection of human melanoma HBL and SK-Mel28 clones that were previously modified and preselected in the $0.5 \mu \mathrm{g} / \mathrm{ml}$ blasticidin-containing medium to express high levels of tetracycline-sensitive repressor (TetR) from the pcDNA 6/TR Invitrogen plasmid. HBL and SK-Mel28 cells expressing both plasmids were preselected in $400 \mu \mathrm{g} /$ $\mathrm{ml}$ geneticin (G418 sulfate) and $0.5 \mu \mathrm{g} / \mathrm{ml}$ blasticidin and cloned using serial dilution assay. The presence of two plasmids, pT-Rex DEST30-H2B-GFP and pcDNA 6/TR, in the individual clones was verified by RT-PCR, and H2B-GFP expression was confirmed by flow cytometry. To induce H2B-GFP expression, cells were incubated for $24 \mathrm{~h}$ with $1 \mu \mathrm{g} / \mathrm{ml}$ tetracycline, which inactivated TetR and derepressed the tetracycline operator $2 \mathrm{X} \mathrm{TetO}_{2}$ (Tet-ON system), permitting H2B-GFP transcription from the CMV promoter. Clones that expressed high, but not toxic, levels of H2B-GFP were chosen for further experimentation. Stably transfected cells were grown in the presence of blasticidin and geneticin to maintain TetR and H2B-GFP genes. Blasticidin was obtained from Gibco $^{\oplus}$, Life Technologies ${ }^{\mathrm{TM}}$, France, and geneticin was obtained from Santa Cruz Biotechnology. RNA extraction was performed following the manufacturer's protocol (RNeasy Kit, Qiagen, Courtaboeuf, France). Primers were designed to amplify 305 bp cDNA fragments for the pcDNA6/TR plasmid and 187 bp cDNA fragments for the pT-Rex DEST30-H2B-GFP plasmid as follows: $1^{\text {st }}$ plasmid: $5^{\text {' }}$ CTGGTCATCATCCTGCCTTT3' and 5'GGCGAGTTT ACGGGTTGTTA3'; $2^{\text {nd }}$ plasmid: 5'ACGTAAACGGCC ACAAGTTG3' and 5'AAGTCGTGCTGCTTCATGT G3'. RNA was transcribed into cDNA using random hexamers, recombinant $\mathrm{RNasin}^{\odot}$ ribonuclease inhibitor (Promega, France) and M-MLV reverse transcriptase (Promega, France). PCR was performed using GoTaq ${ }^{\circ}$ Flexi DNA polymerase (Promega, France).

\section{Generation of melanospheres}

To generate primary spheres, $4 \times 10^{3}$ cells were plated on 24-well plates coated with a $0.5 \mathrm{mg} / \mathrm{ml}$ poly-2-hydroxyethylmetacrylate (polyHEMA) ethanol solution (SigmaAldrich, France) to prevent cell attachment and cultured in DMEM/F12 medium $\left(\right.$ Gibco $^{\circ}$, Life Technologies ${ }^{\mathrm{TM}}$, France), which was supplemented with $20 \mathrm{ng} / \mathrm{ml}$ EGF (Stem Cells Biotechnologies, Vancouver, BC, Canada), 1:50 B27-supplement (Gibco ${ }^{\oplus}$, Invitrogen ${ }^{\text {тм }}$, France), and $20 \mathrm{ng} / \mathrm{ml} \mathrm{rHu}$ bFGF (PromoKine-PromoCell $\mathrm{GmbH}$, Heidelberg, Germany), in a humidified $5 \% \mathrm{CO}_{2}$ incubator at $37^{\circ} \mathrm{C}$ for 7 days. Tumor Necrosis Factor $\alpha$ (TNF) $(0.5 \mu \mathrm{g} / \mathrm{ml})$ from Immunotools, Germany, and/or an inhibitor of the PI3K/AKT signaling, $10 \mu \mathrm{M}$ LY294002, or an inhibitor of NFKB signaling, $1 \mu \mathrm{M}$ BAY 11-7082, which were both obtained from Calbiochem, France, were added at the time of sphere seeding and not re-added during the 7 days of sphere formation. Spheres were dissociated by a brief incubation with trypsin/EDTA solution (Gibco ${ }^{\circ}$, Life Technologies ${ }^{\mathrm{TM}}$, France) and then used as a single cell suspension for all the experiments. Cell viability was evaluated using the 3-(4,5-dimethylthiazol-2-yl)-2,5-diphenyltetrazolium bromide (MTT) assay (Sigma-Aldrich, France). After complete solubilization, the presence of blue formazan was evaluated spectrophotometrically by measuring the absorbance at $562 \mathrm{~nm}$. For the LRCassay, cells were treated with tetracycline $(1 \mu \mathrm{g} / \mathrm{ml})$ for 24 hours at $37^{\circ} \mathrm{C}$ in adherent culture and plated as above. Spheres (larger than $\sim 50$ cells) were counted under the microscope, and sphere-forming units (SFUs) (\%) were estimated according to the formula: number of spheres/ number of plated live cells $\times 100$.

\section{Flow cytometry}

Spheres containing GFP $^{\text {high }}$ cells were dissociated, and single cell suspensions $\left(2 \times 10^{5}\right.$ cells $\left./ 500 \mu \mathrm{l}\right)$ of $\mathrm{HBL}$ or SK-Mel28 cells were incubated for $45 \mathrm{~min}$ on ice in $100 \mu \mathrm{l}$ of RPMI medium with the following primary antibodies: anti-ABCB5 (Rockland, Tebu-Bio, France), which was used at a 1:215 dilution, and antiVEGFR1 (Abcam), anti-Notch (Santa Cruz Biotech), and anti-CD57 (HNK-1) (gift from Dr E. Dupin, Vision Institute, Paris or from Santa Cruz Biotech), which were used at a 1:50 dilution. After incubation, the cells were rinsed with RPMI, centrifuged and resuspended in $100 \mu \mathrm{l}$ of RPMI with a secondary antibody, $\mathrm{Cy}^{\circ}$ goat anti-rabbit IgG $(\mathrm{H}+\mathrm{L})$ or goat anti-mouse (Molecular Probes ${ }^{\oplus}$, Life Technology ${ }^{\mathrm{Tm}}$, France), which was used at a 1:2000 dilution for $30 \mathrm{~min}$ on ice in dark. After incubation, the cells were rinsed with RPMI, centrifuged, resuspended in $500 \mu \mathrm{l}$ of RPMI, and placed on ice before being analyzed by flow cytometry. Propidium iodide (PI)-positive dead cells were gated out and excluded from the analysis. Acquisition was performed on an EPICS-CYAN flow cytometer (Beckman Coulter France S.A.S.) and analyzed using Summit 4.3 software. GFP fluorescence intensities were recorded on the FL1 channel. Quadrants were determined based on negative control staining with a corresponding isotype antibody. FACS sorting: Cell sorting was performed on an FACS-ALTRA sorter (Beckman Coulter France S.A.S.). Spheres were dissociated, and the single cell suspension was adjusted to a concentration of $10^{6}$ cells/ml in RPMI. After excluding cell debris, the collection gates were set according to the negative $\left(\mathrm{GFP}^{\text {low }}\right)$ control containing cells untreated with tetracycline. Cells with positive fluorescence constituted the GFP ${ }^{\text {high }}$ cell subset. The collected cells were centrifuged, rinsed and re-plated for sphere and colony generation. 


\section{Generation of human skin equivalents}

Skin equivalents (SEs) were prepared as described previously [78]. Briefly, dermal equivalents (DEs) were prepared using primary human fibroblasts $\left(3 \times 10^{5} / \mathrm{DE}\right)$ in RPMI with heat-deactivated fetal bovine serum (FBS), $1 \mathrm{mM} \mathrm{NAOH}$ and collagen I (rat tail collagen type I, BD Biosciences, France), which were placed into 6-well plates and allowed to contract for several days until their radii reached $5 \mathrm{~mm}$. To regenerate melanoma cells in a reconstructed epidermis, a mixture of primary keratinocytes $\left(1 \times 10^{5} / \mathrm{SE}\right)$ and $1 \times 10^{4} / \mathrm{SE}$ human melanoma cells with or without sorting were seeded onto DEs and cultured for 7 days in DMEM $\left(\right.$ Gibco $^{\circ}$, Life Technologies ${ }^{\mathrm{Tm}}$, France) supplemented with $10 \%$ FBS in the presence or absence of $0.5 \mu \mathrm{g} / \mathrm{ml}$ TNF. Then, the cultures were lifted at the air-liquid interface to stimulate keratinocyte differentiation. The medium, which was supplemented with $0.5 \mu \mathrm{g} / \mathrm{ml}$ hydrocortisone, was changed every $2-3$ days. After 21-23 days of culture, skin equivalents were dissociated using $4 \mathrm{mg} / \mathrm{ml}$ collagenase for $30 \mathrm{~min}$ at $37^{\circ} \mathrm{C}$ and trypsin/EDTA for an additional $5 \mathrm{~min}$. Then, melanoma cells were counted and plated on 24-well plates coated with polyHEMA in DMEM/F12 for sphere formation.

\section{EdU incorporation by melanosphere cells}

An Alexa Fluor 647 Click-iT Edu Flow Cytometry Assay Kit (Life Technologies) and its accompanied recommendations were used to estimate the proportion of GFPpositive and -negative melanosphere cells in $\mathrm{S}$ phase. Non-cytotoxic $10 \mu \mathrm{M}$ EdU (5-ethynyl-2'-desoxyuridine) was added for 2 hours to melanosphere cultures before harvesting. Melanospheres were dissociated with trypsin/ EDTA, and a suspension of $1 \times 10^{6}$ individual cells was centrifuged, washed twice with $\mathrm{PBS} / 1 \%$ BSA buffer and fixed in $4 \%$ paraformaldehyde solution for 15 minutes at RT in the dark. The fixed cells were permeabilized with saponin solution and incubated with Alexa Fluor ${ }^{\circ} 7$ azide in the supplied buffer for 30 minutes in the dark. Labeled cells were analyzed by flow cytometry. For the detection of EdU with Alexa Fluor 647 azide, we used 633/635 $\mathrm{nm}$ excitation with a red emission filter $(660 / 620 \mathrm{~nm})$. The proportion of melanoma cells that were both EdU-positive and GFP-positive or GFP-negative was estimated by a flow cytometry quadrant analysis determining the percentage of each subpopulation. Negative control was gated using EdU unstained and tetracycline uninduced cells.

\section{Immunocytochemistry}

HBL-H2BGFP melanospheres were cultured for 7 days in the presence or absence of TNF $(0.5 \mu \mathrm{g} / \mathrm{ml})$ and/or LY294002 $(10 \mu \mathrm{M})$, which were both added at seeding. The dissociated melanosphere cells were plated on LabTek chamber glass coverslips (Millicell EZ SLIDE 8-well glass, sterile Merck Milipore, Darmstadt, Germany) at a density of 15000 cells per well. After 24 hours, the adherent cells were fixed in PAF solution, and immunocytochemistry was performed according to the standard procedure. A monoclonal anti-Melan A antibody, which was purchased from Santa Cruz Biotech, was used at a dilution of 1:100, and positive cells were detected with a secondary AlexaFluor 594 goat anti-mouse (Life Technologies), which was used at a dilution of 1:2000. Negative controls were performed by replacing the primary antibody with an irrelevant isotype. Nuclei were counterstained with DAPI. All slides were mounted under a coverslip with Vectashield mounting medium (Vector Laboratories, Nanterre, France) and were photographed using a Leica DMRB LAS3.7 fluorescence microscope.

\section{Western blot analysis}

Western blot analysis was performed using ready-to-use NuPAGE 4\%-12\% Bis-Tris polyacrylamide gels according to the supplier's instructions (Invitrogen ${ }^{\text {Txu }}$, St. Aubin, Paris, France). Blots were probed with the primary antibodies against Actin (Sigma-Aldrich, St. Quentin Fallavier, France), Akt and pAkt (Cell Signaling, France), followed by a horseradish peroxidase-conjugated secondary antibody (Bio-Rad, Marne-la-Coquette, France). Corresponding isotypes were used as controls. Immunodetection was performed using an ECL + chemiluminescence kit from Amersham. The band intensities in immunoblotting were analyzed and quantified using ImageJ and user-supplied algorithms.

\section{Statistical analysis}

The results are expressed as the mean \pm standard error of the mean (SEM) of at least 3 independent experiments each combining spheres from 24 wells unless indicated otherwise. A comparison between means was performed using Student's t-test for unpaired data. When unequal variance was observed, Welch's correction was applied. A comparison between several groups was performed using a one-way analysis of variance, followed by Dunnett's multiple comparison test, using an appropriate control group as the reference. The statistical analyses were performed using GraphPad Prism 4.0 software. A p value of $<0.05$ was considered significant.

\section{Competing interests}

The authors declare that they have no competing interest.

\section{Authors' contributions}

$\mathrm{PO}$ and REM: design of experiments, collection and assembly of data, data analysis and interpretation. SB, NK, JV, and PF: collection and assembly of data, data analysis and interpretation. PS and BM: collection and assembly of data. PF: interpretation and discussion. YT and RP: conception and design, data analysis and interpretation, preparation and writing of the manuscript. All authors read and approved the final version of the manuscript. 


\section{Acknowledgments}

The authors thank Nathalie Jouy (BiCell-IFR114 flow cytometry platform) for her assistance with the flow cytometry analyses and FACS sorting. The authors are grateful to the Department of Plastic Surgery at the Roger Salengro Hospital for providing skin specimens. This research was supported by the Institut National de la Sante et de la Recherche Medicale (INSERM) the Institut National du Cancer (National Cancer Institute) of France and the SILAB-Jean Paufique Corporate Foundation. Y. Touil was supported by the Institut Pour la Recherche sur le Cancer de Lille (IRCL) and by SIRIC ONCOLille R. El Machhour was supported by the Ligue Nationale Contre le Cancer. P. Flamenco was supported by the CPER (Contrat de Plan Etat/Région) program of the Nord - Pas de Calais region. P. Ostyn's graduate study was financed by CHRU Lille and the Region Nord-Pas de Calais.

\section{Author details}

'Inserm U837 Jean-Pierre Aubert Research Center, Institut pour la Recherche sur le Cancer de Lille (IRCL), 1, Place de Verdun 59045, Lille Cedex, France. ${ }^{2}$ Univ Lille Nord de France, F-59000 Lille, France. ${ }^{3} \mathrm{CHULille}$, F-59000 Lille, France. ${ }^{4}$ SIRIC ONCOLille, Lille, France.

\section{Received: 1 July 2014 Accepted: 26 August 2014}

\section{Published online: 17 September 2014}

\section{References}

1. Ossowski L, Aguirre-Ghiso JA: Dormancy of metastatic melanoma. Pigment Cell Melanoma Res 2010, 23:41-56.

2. Strauss DC, Thomas JM: Transmission of donor melanoma by organ transplantation. Lancet Oncol 2010, 11:790-796.

3. Aguirre-Ghiso JA: Models, mechanisms and clinical evidence for cancer dormancy. Nat Rev Cancer 2007, 7:834-846.

4. Chomel J-C, Turhan AG: Chronic myeloid leukemia stem cells in the era of targeted therapies: resistance, persistence and long-term dormancy. Oncotarget 2011, 2:713-727.

5. Alison MR, Lin W-R, Lim SML, Nicholson LJ: Cancer stem cells: in the line of fire. Cancer Treat Rev 2012, 38:589-598.

6. Borst P: Cancer drug pan-resistance: pumps, cancer stem cells, quiescence, epithelial to mesenchymal transition, blocked cell death pathways, persisters or what? Open Biol 2012, 2:120066-120066.

7. Touil Y, Igoudjil W, Corvaisier M, Dessein A-F, Vandomme J, Monté $D$, Stechly L, Skrypek N, Langlois C, Grard G, Millet G, Leteurtre E, Dumont P, Truant S, Pruvot F-R, Hebbar M, Fan F, Ellis LM, Formstecher P, Van Seuningen I, Gespach C, Polakowska R, Huet G: Colon cancer cells escape 5FU chemotherapy-induced cell death by entering stemness and quiescence associated with the c-Yes/YAP axis. Clin Cancer Res Off J Am Assoc Cancer Res 2014, 20:837-846.

8. Essers MAG, Trumpp A: Targeting leukemic stem cells by breaking their dormancy. Mol Oncol 2010, 4:443-450.

9. Tanno T, Matsui W: Development and maintenance of cancer stem cells under chronic inflammation. J Nippon Med Sch 2011, 78:138-145.

10. Kundu JK, Surh Y-J: Emerging avenues linking inflammation and cancer. Free Radic Biol Med 2012, 52:2013-2037.

11. Carswell EA, Old L, Kassel RL, Green S, Fiore N, Williamson B: An endotoxin-induced serum factor that causes necrosis of tumors. Proc Natl Acad Sci U S A 1975, 72:3666-3670.

12. Balkwill F: Tumor necrosis factor or tumor promoting factor? Cytokine Growth Factor Rev 2002, 13:135-141.

13. Mantovani A, Allavena P, Sica A, Balkwill F: Cancer-related inflammation. Nature 2008, 454:436-444.

14. Hruza LL, Pentland AP: Mechanisms of UV-induced inflammation. J Invest Dermatol 1993, 100:35S-41S.

15. Pece S, Tosoni D, Confalonieri S, Mazzarol G, Vecchi M, Ronzoni S, Bernard L, Viale G, Pelicci PG, Di Fiore PP: Biological and molecular heterogeneity of breast cancers correlates with their cancer stem cell content. Cell 2010, 140:62-73.

16. Tumbar T: Defining the epithelial stem cell niche in skin. Science 2004, 303:359-363.

17. Kanda T, Sullivan KF, Wahl GM: Histone-GFP fusion protein enables sensitive analysis of chromosome dynamics in living mammalian cells. Curr Biol CB 1998, 8:377-385.

18. Tesio M, Trumpp A: Breaking the cell cycle of HSCs by p57 and friends. Cell Stem Cell 2011, 9:187-192.
19. Schatton T, Frank NY, Frank MH: Identification and targeting of cancer stem cells. BioEssays 2009, 31:1038-1049.

20. Boiko AD, Razorenova OV, van de Rijn M, Swetter SM, Johnson DL, Ly DP, Butler PD, Yang GP, Joshua B, Kaplan MJ, Longaker MT, Weissman IL: Human melanoma-initiating cells express neural crest nerve growth factor receptor CD271. Nature 2010, 466:133-137.

21. Frank NY, Schatton T, Kim S, Zhan Q, Wilson BJ, Ma J, Saab KR, Osherov V, Widlund HR, Gasser M, Waaga-Gasser A-M, Kupper TS, Murphy GF, Frank MH: VEGFR-1 expressed by malignant melanoma-initiating cells is required for tumor growth. Cancer Res 2011, 71:1474-1485.

22. Dupin E, Coelho-Aguiar JM: Isolation and differentiation properties of neural crest stem cells. Cytometry A 2013, 83A:38-47.

23. Liu J, Sato C, Cerletti M, Wagers A: Notch signaling in the regulation of stem cell self-renewal and differentiation. Curr Top Dev Biol 2010, 92:367-409. Elsevier.

24. Grivennikov SI, Greten FR, Karin M: Immunity, inflammation, and cancer. Cell 2010, 140:883-899.

25. Croft M, Benedict CA, Ware CF: Clinical targeting of the TNF and TNFR superfamilies. Nat Rev Drug Discov 2013, 12:147-168.

26. Reynolds BA, Weiss $\mathrm{S}$ : Generation of neurons and astrocytes from isolated cells of the adult mammalian central nervous system. Science 1992, 255:1707-1710.

27. Perego M, Alison MR, Mariani L, Rivoltini L, Castelli C: Spheres of influence in cancer stem cell biology. J Invest Dermatol 2010, 131:546-547.

28. Hirschhaeuser F, Menne H, Dittfeld C, West J, Mueller-Klieser W, KunzSchughart LA: Multicellular tumor spheroids: an underestimated tool is catching up again. J Biotechnol 2010, 148:3-15.

29. Davies MA, Samuels Y: Analysis of the genome to personalize therapy for melanoma. Oncogene 2010, 29:5545-5555.

30. Chartrain M, Riond J, Stennevin A, Vandenberghe I, Gomes B, Lamant L, Meyer N, Gairin JE, Guilbaud N, Annereau JP: Melanoma chemotherapy leads to the selection of ABCB5-expressing cells. PLOS ONE 2012, 7:e36762.

31. Fang D, Nguyen TK, Leishear K, Finko R, Kulp AN, Hotz S, Van Belle PA, Xu X, Elder DE, Herlyn M: A tumorigenic subpopulation with stem cell properties in melanomas. Cancer Res 2005, 65:9328-9337.

32. Eves P, Layton C, Hedley S, Dawson RA, Wagner M, Morandini R, Ghanem G, Mac Neil S: Characterization of an in vitro model of human melanoma invasion based on reconstructed human skin. Br J Dermatol 2000, 142:210-222.

33. Li L, Fukunaga-Kalabis M, Herlyn M: The three-dimensional human skin reconstruct model: a tool to study normal skin and melanoma progression. J Vis Exp JoVE 2011, 54:e2937.

34. Touil Y, Zuliani T, Wolowczuk I, Kuranda K, Prochazkova J, Andrieux J, Le Roy H, Mortier L, Vandomme J, Jouy N, Masselot B, Ségard P, Quesnel B, Formstecher P, Polakowska R: The PI3K/AKT signaling pathway controls the quiescence of the Low-Rhodamine123-retention cell compartment enriched for melanoma stem cell activity. STEM CELLS 2013, 31:641-651.

35. Landsberg J, Kohlmeyer J, Renn M, Bald T, Rogava M, Cron M, Fatho M, Lennerz V, Wölfel T, Hölzel M, Tüting T: Melanomas resist T-cell therapy through inflammation-induced reversible dedifferentiation. Nature 2012, 490:412-416.

36. Takizawa H, Regoes RR, Boddupalli CS, Bonhoeffer S, Manz MG: Dynamic variation in cycling of hematopoietic stem cells in steady state and inflammation. J Exp Med 2011, 208:273-284.

37. Jiang B, Liu L: Chapter 2 PI3K/PTEN Signaling in Angiogenesis and Tumorigenesis. In Adv Cancer Res, Volume 102. Edited by Vande Woude GF, Klein G. Elsevier: 2009:19-65.

38. Kimura T, Nakano T: Regulation of Stem Cell Systems by PI3K/Akt Signaling. In Regul Netw Stem Cells. Edited by Rajasekhar VK, Vemuri MC. New York: Humana Press; 2009:309-318.

39. Ito K, Suda T: Metabolic requirements for the maintenance of self-renewing stem cells. Nat Rev Mol Cell Biol 2014, 15:243-256.

40. Sykes SM, Lane SW, Bullinger L, Kalaitzidis D, Yusuf R, Saez B, Ferraro F, Mercier F, Singh H, Brumme KM, Acharya SS, Scholl C, Tothova Z, Attar EC, Fröhling S, DePinho RA, Gilliland DG, Armstrong SA, Scadden DT: AKT/ FOXO signaling enforces reversible differentiation blockade in myeloid leukemias. Cell 2011, 146:697-708.

41. Wray J, Kalkan T, Gomez-Lopez S, Eckardt D, Cook A, Kemler R, Smith A: Inhibition of glycogen synthase kinase-3 alleviates Tcf3 repression of the 
pluripotency network and increases embryonic stem cell resistance to differentiation. Nat Cell Biol 2011, 13:838-845.

42. Davies MA: The role of the PI3K-AKT pathway in melanoma. Cancer J Sudbury Mass 2012, 18:142-147.

43. Russo A, Ficili B, Candido S, Pezzino FM, Guarneri C, Biondi A, Travali S, McCubrey JA, Spandidos DA, Libra M: Emerging targeted therapies for melanoma treatment (Review). Int J Oncol 2014, 45:516-524.

44. Richmond A: NF-KB, chemokine gene transcription and tumour growth. Nat Rev Immunol 2002, 2:664-674.

45. Smale ST: Hierarchies of NF-KB target-gene regulation. Nat Immunol 2011, 12:689-694.

46. Ben-Neriah Y, Karin M: Inflammation meets cancer, with NF-kB as the matchmaker. Nat Immunol 2011, 12:715-723.

47. Baldridge MT, King KY, Goodell MA: Inflammatory signals regulate hematopoietic stem cells. Trends Immunol 2011, 32:57-65.

48. Meng F, Liu L, Chin PC, D'Mello SR: Akt is a downstream target of NF-kappa B. J Biol Chem 2002, 277:29674-29680.

49. Oeckinghaus $A$, Hayden MS, Ghosh S: Crosstalk in NF-KB signaling pathways. Nat Immunol 2011, 12:695-708.

50. Sundaramoorthy S, Ryu MS, Lim IK: B-cell translocation gene 2 mediates crosstalk between PI3K/Akt1 and NFkB pathways which enhances transcription of MnSOD by accelerating IKBa degradation in normal and cancer cells. Cell Commun Signal CCS 2013, 11:69-83.

51. Moore N, Lyle S: Quiescent, slow-cycling stem cell populations in cancer: a review of the evidence and discussion of significance. J Oncol 2011, 2011. Article PMID 396076,11 pages (doi:10.1155/2011/39606 http://www. hindawi.com/journals/jo/2011/396076/).

52. Cheung TH, Rando TA: Molecular regulation of stem cell quiescence. Nat Rev Mol Cell Biol 2013, 14:329-340.

53. Paez D, Labonte MJ, Bohanes P, Zhang W, Benhanim L, Ning Y, Wakatsuki T, Loupakis F, Lenz H-J: Cancer dormancy: a model of early dissemination and late cancer recurrence. Clin Cancer Res 2011, 18:645-653.

54. Shigdar S, Li Y, Bhattacharya S, O'Connor M, Pu C, Lin J, Wang T, Xiang D, Kong L, Wei MQ, Zhu Y, Zhou S, Duan W: Inflammation and cancer stem cells. Cancer Lett 2014, 345:271-278.

55. Schuettpelz LG, Link DC: Regulation of hematopoietic stem cell activity by inflammation. Front Immunol 2013, 4:204-213.

56. Cicalese A, Bonizzi G, Pasi CE, Faretta M, Ronzoni S, Giulini B, Brisken C, Minucci S, Di Fiore PP, Pelicci PG: The tumor suppressor p53 regulates polarity of self-renewing divisions in mammary stem cells. Cell 2009, 138:1083-1095.

57. Nicholson KM, Anderson NG: The protein kinase B/Akt signalling pathway in human malignancy. Cell Signal 2002, 14:381-395.

58. Martini M, De Santis MC, Braccini L, Gulluni F, Hirsch E: PI3K/AKT signaling pathway and cancer: an updated review. Ann Med 2014, 46:372-383.

59. Wilson BJ, Saab KR, Ma j, Schatton T, Putz P, Zhan Q, Murphy GF, Gasser M, Waaga-Gasser AM, Frank NY, Frank MH: ABCB5 maintains melanomainitiating cells through a proinflammatory signaling circuits. Cancer Res 2014, 74:4196-4207.

60. Mani SA, Guo W, Liao M-J, Eaton EN, Ayyanan A, Zhou AY, Brooks M, Reinhard F, Zhang CC, Shipitsin M, Campbell LL, Polyak K, Brisken C, Yang J, Weinberg RA: The epithelial-mesenchymal transition generates cells with properties of stem cells. Cell 2008, 133:704-715.

61. Chaffer CL, Brueckmann I, Scheel C, Kaestli AJ, Wiggins PA, Rodrigues LO, Brooks M, Reinhardt F, Su Y, Polyak K, Arendt LM, Kuperwasser C, Bierie B, Weinberg RA: Normal and neoplastic nonstem cells can spontaneously convert to a stem-like state. Proc Natl Acad Sci 2011, 108:7950-7955.

62. Poole A, Knowland N, Cooper E, Cole R, Wang H, Booth L, Kacer D, Tarantini F, Friesel R, Prudovsky I: Transitory FGF treatment results in the long-lasting suppression of the proliferative response to repeated FGF stimulation. J Cell Biochem 2014, 115:874-888.

63. Tang DG: Understanding cancer stem cell heterogeneity and plasticity. Cell Res 2012, 22:457-472.

64. Bhat-Nakshatri P, Appaiah H, Ballas C, Pick-Franke P, Goulet R Jr, Badve S, Srour EF, Nakshatri H: SLUG/SNAI2 and tumor necrosis factor generate breast cells with CD44+/CD24- phenotype. BMC Cancer 2010, 10:411-427.

65. Amoyel M, Bach EA: Cell competition: how to eliminate your neighbours. Dev Camb Engl 2014, 141:988-1000.

66. Levayer R, Moreno E: Mechanisms of cell competition: themes and variations. J Cell Biol 2013, 200:689-698.
67. Klein CA: Selection and adaptation during metastatic cancer progression. Nature 2013, 501:365-372.

68. Wang CQF, Akalu YT, Suarez-Farinas M, Gonzalez J, Mitsui H, Lowes MA, Orlow SJ, Manga P, Krueger JG: IL-17 and TNF synergistically modulate cytokine expression while suppressing melanogenesis: potential relevance to psoriasis. J Invest Dermatol 2013, 133:2741-2752.

69. Widera D, Mikenberg I, Elvers M, Kaltschmidt C, Kaltschmidt B: Tumor necrosis factor a triggers proliferation of adult neural stem cells via IKK/NF-KB signaling. BMC Neurosci 2006, 7:64-82.

70. Mori T, Sato Y, Miyamoto K, Kobayashi T, Shimizu T, Kanagawa H, Katsuyama E, Fujie A, Hao W, Tando T, Iwasaki R, Kawana H, Morioka H, Matsumoto M, Saya $H$, Toyama Y, Miyamoto T: TNFa promotes osteosarcoma progression by maintaining tumor cells in an undifferentiated state. Oncogene 2013, 33:4236-4241

71. Rusten LS, Jacobsen FW, Lesslauer W, Loetscher H, Smeland EB, Jacobsen SE: Bifunctional effects of tumor necrosis factor alpha (TNF alpha) on the growth of mature and primitive human hematopoietic progenitor cells: involvement of p55 and p75 TNF receptors. Blood 1994, 83:3152-3159.

72. Pronk CJH, Veiby OP, Bryder D, Jacobsen SEW: Tumor necrosis factor restricts hematopoietic stem cell activity in mice: involvement of two distinct receptors. J Exp Med 2011, 208:1563-1570.

73. Dybedal I: Tumor necrosis factor (TNF)-mediated activation of the $\mathrm{p} 55$ TNF receptor negatively regulates maintenance of cycling reconstituting human hematopoietic stem cells. Blood 2001, 98:1782-1791.

74. Roesch A, Fukunaga-Kalabis M, Schmidt EC, Zabierowski SE, Brafford PA, Vultur A, Basu D, Gimotty P, Vogt T, Herlyn M: A temporarily distinct subpopulation of slow-cycling melanoma cells is required for continuous tumor growth. Cell 2010, 141:583-594.

75. Dey-Guha I, Wolfer A, Yeh AC, Albeck JG, Darp R, Leon E, Wulfkuhle J, Petricoin EF, Wittner BS, Ramaswamy S: Asymmetric cancer cell division regulated by AKT. Proc Natl Acad Sci 2011, 108:12845-12850.

76. Ghanem GE, Comunale G, Libert A, Vercammen-Grandjean A, Lejeune FJ: Evidence for alpha-melanocyte-stimulating hormone (alpha-MSH) receptors on human malignant melanoma cells. Int J Cancer J Int Cancer 1988, 41:248-255.

77. Le Roy H, Zuliani T, Wolowczuk I, Faivre N, Jouy N, Masselot B, Kerkaert J-P, Formstecher P, Polakowska R: Asymmetric distribution of epidermal growth factor receptor directs the fate of normal and cancer keratinocytes in vitro. Stem Cells Dev 2010, 19:209-220.

78. Haake AR, Polakowska RR: UV-induced apoptosis in skin equivalents: inhibition by phorbol ester and Bcl-2 overexpression. Cell Death Differ 1995, 2:183-193.

doi:10.1186/s12964-014-0052-z

Cite this article as: Ostyn et al.: Transient TNF regulates the selfrenewing capacity of stem-like label-retaining cells in sphere and skin equivalent models of melanoma. Cell Communication and Signaling 2014 12:52

\section{Submit your next manuscript to BioMed Central and take full advantage of:}

- Convenient online submission

- Thorough peer review

- No space constraints or color figure charges

- Immediate publication on acceptance

- Inclusion in PubMed, CAS, Scopus and Google Scholar

- Research which is freely available for redistribution 